\title{
A Study on the Recital Necessities and Challenges of the 5th Generation Wireless Networks
}

\section{Azhi Aziz Salih}

Department of Mathematics, College of Basic Education, Salahaddin University ,Erbil, Kurdistan Region, Iraq azhi.salih@su.edu.krd

\section{ARTICLE INFO}

\section{Article History:}

Received: 10/4/2021

Accepted: 22/4/2021

Published: Spring 2021

\section{Keywords:}

$5 G$ wireless network, Internet connectivity, Speedy internet, Recital necessities, Challenges of $5^{\text {th }}$ generation wireless network.

Doi:

10.25212/lfu.qzj.6.2.40

\begin{abstract}
In the ever-changing digital era, everybody enjoys speed, and more so speedy internet connections. Therefore, as most major telecom service providers are operating around the clock to develop internet connections even faster. The electronic devices human beings have become so dependent on such as smartphones, homes, cars, laptops and watches need stable internet connections. All these innovations require always-on and high-speed internet. The fifth generation (5G) wireless network couldn't have come at a much better time as devices and vehicular needing such strong connectivity are explosion every nanosecond and there is more technological progress. Taleb (2017) opine that the cellular network infrastructure is seen as one of the missing pieces needed to accelerate the optimization of the existing technology available today. 5G technology promises a future of improved data rates, quality service, decreased latency and improved capacity. It promises recital necessities which will be discussing in the paper under the sustainability and efficiency requirements. The paper will also discourse the challenges that the $5 \mathrm{G}$ mobile network architecture faces in its journey to bring the fastest internet connectivity ever seen.
\end{abstract}




\section{Introduction}

Bill Gates once said, "Never before has innovation promised so much to a lot of people in such a short span of time". According to Johansson et al. (2012), the OECD stated that technological innovations held to address the world's developmental problems such as eradication of diseases, access to drinking water and reduction of hunger. Mobile communications have transformed from what they used to do - the systems back then were only capable of transmitting voice conversations for many users to a system that supports multiple devices that transport data rather than just voice. Data communications have different needs that go beyond voice and the current 4G/LongTerm Evolution networks will have reached their limits in the near future. According to Wang (2014), a study opines that there will be more than 7 trillion loT devices by 2017. And thus, sustainable and efficient network structures are necessary to meet the many needs of future users (Andrews et al., 2014). The world as of now and in the future depends on connectivity gauging from artificial intelligence, self-driving vehicles and telemedicine and the undreamt innovations that human beings hope will make life easier, safer, and healthier.

The 21st century has witnessed many important innovations in the history of humankind such as 3D printing which is a game changer in the medical field and the Internet of Things (IOT), artificial intelligence, and online streaming, among others. As opposed to previous centuries characterized by a government-controlled innovation environment, the 21st century has seen a great shift with the development of accelerated technologies and access to information for everyone (National Academies of Sciences, Engineering, and Medicine, 2019). Though these are great innovations, they have not yet reached the full potential and there is a deficiency of better internet connectivity by reliable technology architecture. The evolution of internet technology has come from first generation (1G) to fourth generation (4G) technology. This is where the 5th Generation wireless network comes in - it is the fifth era portable system that promises to be multipurpose for machines, gadgets, and items (Ayaz et al., 2020). The technology was birthed by NASA together with $\mathrm{m} 2 \mathrm{mi}$ Corporation back in 2008. It is the faster and much improved wireless network that comes after 1G, 2G, 3G and 4G cellular networks. The fifth generation loT is expected 
to communicate for multiple connected devices with the right balance of speed, cost and latency. In fact, according to Paudel (2018), the mobile network architecture has guaranteed that it will have better services than the current 4G, LTE networks as it will provide a data transfer capacity of over $10 \mathrm{Gbs}$ (over 600 times faster than 4G) and a sub-1-millisecond dormancy. According to Chen (2020), the $5 \mathrm{G}$ requirements that will benefit organizations include greater bandwidth (limit), faster speeds and improved capacity. The paper discusses the recital necessities and challenges of the 5th generation (5G) wireless network.

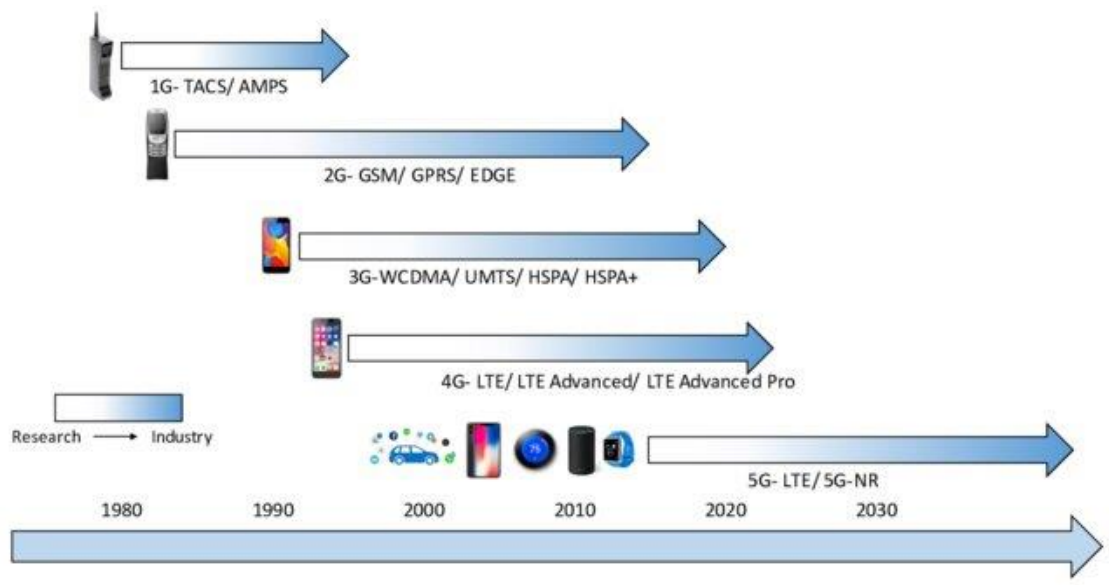

Figure 1 Mobile Communications Evolution

\section{2- Recital Necessities for 5G Wireless Networks}

\section{2-1 Requirements to be met by the Necessities}

In recent years, there have been opinions of what the final form of $5 G$ technology should be. There is a high demand for data usage and speeds that at the same time should be cost effective. There are so many requirements and users will expect the $5 \mathrm{G}$ wireless technology to meet their needs. They include sustainability and efficiency requirements and other needs that this fifth-generation technology is expected to fulfil. 


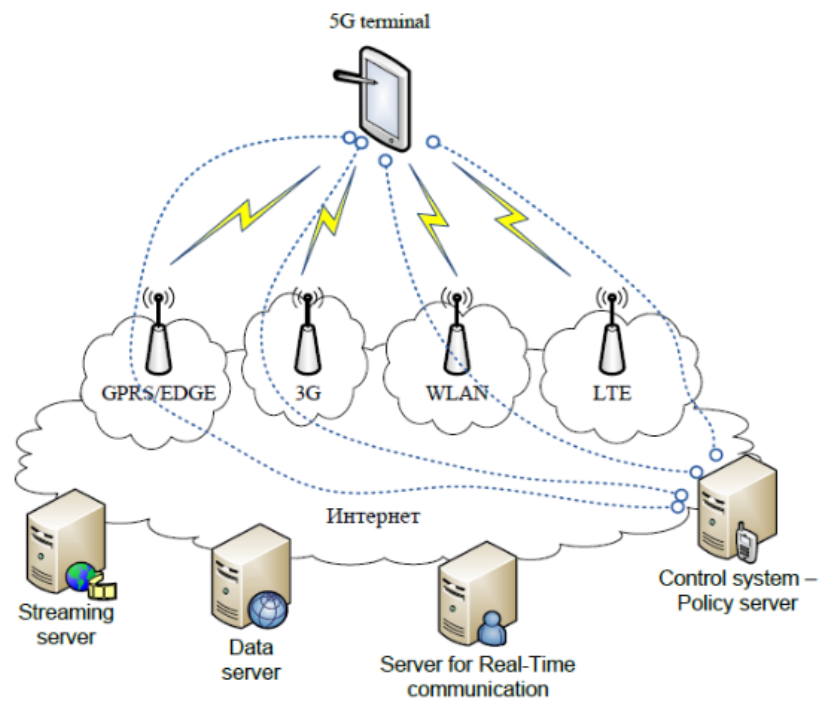

Figure 2 5G Mobile Network Design

\section{2-1-1 Sustainability Requirements}

Currently, the networks available are not sufficient enough to handle the explosive loT and technological developments. There are many complexities and challenges involved if the world was to rely on the 4G, LTE networks operating today. competition for these resources will result in the deployment of additional RATs and possibly less features being made available for those who already use and benefit from the current RATs (Liu \& Jiang, 2016). There would be challenges in coexistence and interferences because of the fragmented spectrum and the energy levels, costs per bit and complexity of networks cannot handle the traffic growth and multiple connected devices of the future (Liu \& Jiang, 2016). As such, the $5 G$ architecture should have very good capabilities to achieve sustainability such as high network capacity, flexible architecture and have various spectrum resources.

\subsubsection{Efficiency Requirements}

The 1000-time growth of network demands of the future requires a level of efficiency from the coming $5 \mathrm{G}$ wireless network. The three most important factors that $5 \mathrm{G}$ must address are energy consumption, cost and the use of spectrum. Therefore, the 5G 
technology provides must up their game and make improvements in spectrum efficiency (3-5 times), cost efficiency (over 100 times) and energy efficiency (over 100 times) (Liu \& Jiang, 2016). The operators must also consider other aspects of providing efficiency such as network slicing, edge computing, Network Functions Virtualization (NFV/Software Defined Networking (SDN) to ensure quality customer experience, high data speeds and low latency among other benefits.

\subsubsection{Hyper-connected view}

The ultimate form of $5 \mathrm{G}$ wireless technology is expected to provide wider coverage and be available all times. A new radio technology would be necessary to enable low usage of power.

\subsubsection{Next-generation radio-access technology}

This requirement is about the specifications for latency and data rates among other specifications. This would set the fifth generation wireless network to be unique from the $4 \mathrm{G}$ network and other earlier services.

\subsection{The Recital Necessities (Capabilities of 5th Generation Technology)}

$5 \mathrm{G}$ must outperform previous networks. For this next-generation wireless technology to meet the requirements mentioned above, desired user needs and challenges of previous networks, it have accommodate all those aspects in its definition without overloading its systems. The $5 \mathrm{G}$ network is expected to be driven by some 8 specification requirements, normally presented as a blooming flower. The capabilities include peak data rates of up to $10 \mathrm{Gbps}$ (10 to 100 times improvement over the 4G networks), end to end latency of 1 millisecond, 1000x bandwidth per unit area, over $100 x$ connected devices in a unit area, all-round availability (99.999\%), 90\% reduction in the energy usage, long-lasting battery life (10-year battery life for low power loT devices and 100\% coverage (Liu \& Jiang, 2016). Among these requirements/capabilities, the most important, known as the $5 \mathrm{G}$ golden triangle are connection density, latency and throughput/user-experienced data rate (Ahmad, 2019). The requirements are presented as a blooming flower where the leaves and flowers depend on each other (Liu \& Jiang, 2016). The petals are the six primary 5G 


\section{QALAAI ZANISTSCIENTIFIC JOURNAL}

A Scientific Quarterly Refereed Journal Issued by Lebanese French University - Erbil, Kurdistan, Iraq

Vol. (6), No (2), spring 2021

ISSN 2518-6566 (Online) - ISSN 2518-6558 (Print)

capabilities for performance requirements and the leaves are representative of the capabilities of efficiency requirements (Liu \& Jiang, 2016). The capabilities work together to provide the best experience for the users.

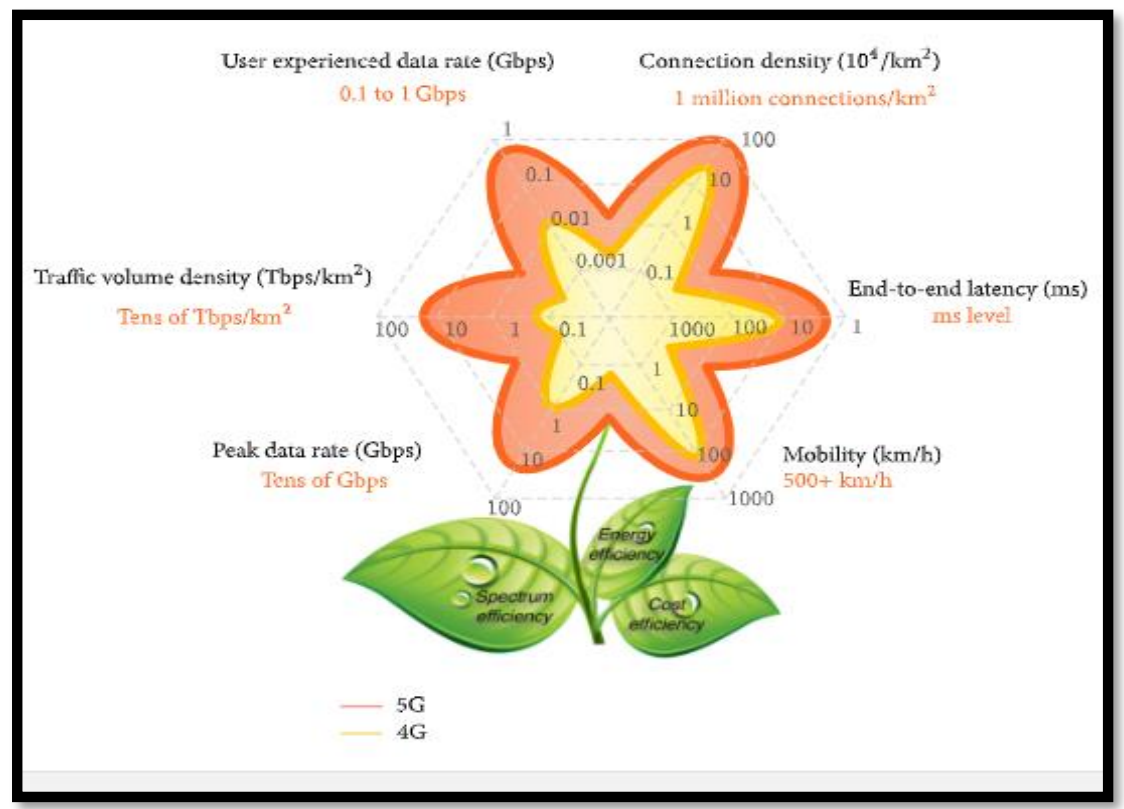

Figure 35 G Capabilities

\subsubsection{Increased Traffic Volume/More Capacity}

There is a need to support more capacity in the future. It is predicted that $5 \mathrm{G}$ network will support almost 1000 times increase in traffic volume compared to the current networks. In 2013, it was estimated that the mobile traffic had grown to almost 70\%, topping to about 2.5 exabytes per month. According to Dahlman (2014), experts predicted that the traffic jam willhave increased by 1000 times more in 2025 . Architects predicted a growth of up to ten times monthly as at 2019. Rappaport of the New York University Wireless research (2015) opined that 4G network cannot meet the new demand of more capacity. The radio technology advancements and getting new spectrum that $4 G$ has been using are reaching their limits. The $5 G$ network architects say that the total capacity will be increased through more 
channels (improved spectrum efficiency), greater bandwidth (more spectra), more networks (cells) and better ratios of signal to noise (Wang, 2014). The $5 \mathrm{G}$ network architects hope to give an edge to the technology by increasing its capacity.

\subsubsection{Peak Data Rates}

The biggest advantage that the 5th generation wireless networks will possess is higher throughput, that will be more that offered by 3G and 4G. 5G architects hope to deliver at least ten times more than the current data rates (10Gbps throughput). The current data rates are limited just like the capacity offered. They are limited because of increased usage of the same frequency that limits the bandwidth amount used per device just like the limits of the backhaul, fronthaul and backbone capabilities (Agyapong, 2014). The increase of data rates by $5 G$ architects will be done via Enhanced Mobile Broadband (eMBB) giving the structure a platform for services such as AR, VR and UHD (Yu et al., 2017). Higher data rates will be one of the biggest capability of $5 \mathrm{G}$ network.

\subsubsection{Lower Latency}

There is a higher demand for always-available and always-on wireless networks. Connected devices like self-driving cars, traffic control and healthcare procedures (remote surgical processes) are limited by latency. The current network models do not support the low-latency and high reliability requirements needed by users in the future (Agyapong, 2014). The earlier mobile telecoms used static or latentindependent data like emails and websites then higher data rates enabled videostreaming which affected by latency. The advanced technologies like remotecontrolled robots used in the medical field and video-conferencing should not be limited by latency as they need to function properly (Agyapong, 2014). 5G architects hope to reach latency levels below 10 milliseconds that will challenge the network layout and physic laws. Low latency is necessary for instantaneous and reliable communications needed in technologies like self-automated cars. 


\subsubsection{Connectivity for Massive Number of Devices (Connectivity Density)}

The $5 \mathrm{G}$ network can support up to a million connections per square kilometer. with increase of loT applications and devices such as Smart Grids, Wearable Tech, Homes and Cities, there is a need for higher connection density, which $5 \mathrm{G}$ networks can provide (Wang, 2014)6). It will enable Mass-Machine Time Communication (M-MTC) usages, thus meeting user demands. With the increase in popularity of IoT applications (i.e., Smart Wearable Technology, Smart Home Technology, Smart Cities, Smart Grids) the high connection density of $5 G$ is a vital capability that will enable Mass-Machine Time Communication (M-MTC) use cases and satisfy the demands of a digital society. 4G technology is incapable of supporting a large number of devices because its systems are not connected to the short-distance communication protocols that have yet to be established to communicate with one another (Panwar, Sharma \& Singh, 2016).5G hopes to create a common system that will support multiple devices that have different use cases.

\subsubsection{Reduction in Energy Usage and Cost}

Currently, it is difficult to balance between the increased demand of users and reduced costs and the energy required to communicate within a network. 5G architects predict a $90 \%$ reduction in network energy usage for the new wireless technology. It is expected that even low-powered devices like sensors will run on a battery for many years (Dahlman, 2014). Radio network power usages are now using $70-80 \%$ of energy usage and this is making the costs quite high. Low power consumption will allow connected devices to operate for many months or years. The $5 \mathrm{G}$ technology will reduce energy usage and also maintain affordable costs.

\subsubsection{The Quality of Experience}

This is the perception of a user on how using a device meets their expectations. It is about the right trade-offs between the different requirements like high data rates and low latency. The $5 \mathrm{G}$ wireless technology will ensure there is a balance and keep a consistent experience at all times. 


\section{Challenges of $5 \mathrm{G}$ Wireless Networks}

Though the 5th generation wireless network has immense capabilities to meet the increased demands for users in the future, architects have been met with several challenges in its deployment and implementation. These challenges can be grouped as technical and non-technical challenges (social, business and regulation problems).

\subsection{Technical Issues}

The architects of fifth generation wireless technology have met various technical issues. They include D2D, mmWave communications, technology maturity, backhaul, EMF level and security challenges.

\subsection{1 mmWave Communications}

This is one huge challenge in implementing $5 \mathrm{G}$ network. mmWave communications will be an important feature of the $5 \mathrm{G}$ mobile network that will be used to provide services such as VR, AR and UHDV (Elkashlan et al., 2015). It will meet the traffic demands and reduce the effect of the wireless bandwidth. However, the mmWave communications block electromagnetic signals and there is a challenge in the design of circuits (Taheribakhsh et al., 2020). The waves which are around $60 \mathrm{GHz}$ band can be blocked by barriers like furniture and people (Elkashlan et al., 2015). Human activities show that a channel may be blocked $1-2 \%$ by around 1-5 people and it increases linearly as the device gets closer to the service cell edge.

\subsubsection{D2D Communications}

With D2D communications, $5 \mathrm{G}$ has two main challenges. There is a challenge in limiting and controlling the interference among the microcell and D2D devices as the major body for resource allocation, communicating and management of interference (Taheribakhsh et al., 2020). There is equally no security and privacy in such communication as it will be possible to route a user's data through other user's devices (Tehrani, 2014). The $5 G$ technology is part of a system known as Authentication and Key Agreement (AKA) - this system is meant to establish trust between networks. However, this system will make it easy to eavesdrop on people's live conversation and even track those using nearby phones. 


\subsubsection{Backhaul Challenges}

$5 \mathrm{G}$ promises a network with increased capacity. They need to develop better telecommunication features to accommodate the 1000 times traffic volume - they will do this using the backhaul network. It is a network that connects the access network such as eNB to the central network and has features like copper, microwaves, satellite and fiber (Bernardos et al., 2013). There is inadequate fiber networks needed to support the low latency and high data rates requirements, which is a major challenge facing operators in the deployment of backhaul networks for small cell devices. Unique solutions to address the backhaul management issue include mmWave communications or SDNs (Ahmad et al., 2018). These backhaul issues are problems with the $5 \mathrm{G}$ implementation.

\subsubsection{Security Problems}

The $5 \mathrm{G}$ network uses new technologies such as NFV/SDN as its infrastructure to provide the use cases and services. Service security is only provided if the infrastructure is secure. In $5 \mathrm{G}$ technology, the functions have been made virtual and the structure resources are shared, hence raising security concerns. $5 \mathrm{G}$ network also has a security heterogeneity issue as it supports different services that have various requirements like eMBB and URLLC (Taheribakhsh et al., 2020). They all have different security requirements - IOT needs light security while URLLC needs high efficient security (Ahmad et al., 2018). A multi-level infrastructure system will be necessary to support any security threats.

\subsubsection{Technology Maturity}

Though the $5 \mathrm{G}$ operators have started building their services, other things cannot manifest because of insufficient technology maturity. There is a need of a maturity level to help in implementing different services need for the technologies used by the $5 \mathrm{G}$ network like SDN, RAN or NFV. The maturity issue exists because of fragmentation and focusing on specific tech (Obiodu \& Giles, 2017). The $5 G$ operators face this maturity issue in the implementation of their network. 


\subsection{Non-Technical Issues}

Non-technical issues are those that affect the social and business aspects of users of $5 G$ network.

\subsubsection{Business Models}

A challenge for ICT provides is that they may need to show what profits and added value their idea brings to the table. The same challenge faces the $5 \mathrm{G}$ architects - what opportunities will their business models be creating for vendors, investors and operators? (Taheribakhsh et al., 2020). Operators would want a model that addresses economic aspects and brings in good benefits and investment. However, some 5G features like mmWave communications are costly and the investment in the technology may not bring sufficient profits (Nyström et al., 2019). The architects must therefore consider the various economic and market aspects to address this challenge.

\subsubsection{Cost of Investment}

In the $5 G$ wireless technology, the user demands require core and radio network rebuilding which utilize complex technologies mostly. Microcells, NFV and SDN are good examples of these technologies (Obiodu \& Giles, 2017). Deploying these technologies such as microcells in rural areas can be very costly and because of the low usage by people, it may never bring insufficient profits. The OPEX of the available networks will also add to the costs of the future $5 \mathrm{G}$ network (Taheribakhsh et al., 2020). Backhaul management needed for putting up fibers is also very expensive. Overall, for successful implementation of the $5 \mathrm{G}$ infrastructure, the costs of investment must be assessed and analyzed as they tend to be high.

\subsubsection{High Costs of Building and Buying the Network}

The building and purchasing of a network is very costly. The operators will raise the money for building it by increasing the customer charges. LTE incurred very high costs initially and so will 56 that hopes to improve the gaps left by previous networks. Research has shown that the total spending on $5 \mathrm{G}$ for the world will reach around $\$ 88$ billion by 2023 (Taheribakhsh et al., 2020). When the network becomes viable, it 
will be connected to robots, cars, smart cities and homes, and appliances. Users and investors may have to part with high charges as operators will need the revenue to build and buy the network.

\subsubsection{Illiteracy}

The $5 \mathrm{G}$ wireless network is making an entrance into a world with both cultural and digital illiteracy levels. In the use of the complex services offered by this technology, illiteracy is a huge threat that will affect its adoption and the profits to the operators (Taheribakhsh et al., 2020). Most people may not have gone to school or do not have digital skills to maneuver around the $5 \mathrm{G}$ services. Some cultures prohibit the girl-child from attending school, while some do not see the need for education, and this translates to lack of literacy in certain areas such as the use of networks like 5G. However, operators could look at this as a market opportunity to provide digital education for their services. Digital illiteracy is an issue that stalls the implementation of $5 \mathrm{G}$ network.

\subsection{Regulation Challenges}

The regulation issues faced by 56 network architects are due to the inefficiencies of their spectrum such as spectrum fragmentation and spectrum management.

\subsubsection{Spectrum Management}

This is yet another huge issue. Though there will be local and specialized provides for the $5 \mathrm{G}$ network, it is difficult to tell whether the microcells will bring new opportunities for other people or cause monopoly by the incumbent operators (Taheribakhsh et al., 2020). Incumbent competitors may charge highly for the connectivity and backhaul and some areas may not give permits to new entrants to work in their locality. The auctioning of spectrum will create incumbent monopolies. The problems of spectrum management will interfere with the access to the technology and may mean high charges for rural users (Hudson,2019). Operators and provides must assess this challenge for successful implementation. 


\subsubsection{Spectrum Fragmentation}

$5 \mathrm{G}$ networks will use around $6 \mathrm{GHz}$ spectrum. Operators will do some fragmentation of the spectrum to try and deliver services quickly. However, the fragmentation could cause problems of interoperability among the operators and vendors, thus reducing the efficiency and sustainability of the network (Taheribakhsh et al., 2020). The spectrum trading could be considered and regulators should seek to have a unified $5 \mathrm{G}$ spectrum. Fragmentation also causes problems in developing the commercial services of this new generation technology.

\subsection{Fifth Generation Network Challenges in Iraq}

\subsubsection{The require for a spectrum}

The rest of the world may as of now by rolling out the $5 \mathrm{G}$ network to its clients but, in Iraq, the $5 \mathrm{G}$ range is however to be distributed. This implies full-fledged trials are still pending which is required for telecom administrators to test their innovation. "Iraq needs range, let's begin there. It was exceptionally promising to listen that, sometime recently the conclusion of the budgetary year, we ought to have the $5 \mathrm{G}$ range sell-off in Iraq.

\subsubsection{Spectrum is as well costly}

One of the reasons that the $5 \mathrm{G}$ range sell-off has been deferred in Iraq is since its too costly for telecom companies. Iraq's debt-ridden administrators are still reeling beneath the weight to keep $4 \mathrm{G}$ costs moo. But, there may be trust in the skyline. "They will come up with inventive approach arrangements for estimating the range. This makes a difference for their clients, the administrators, to begin bringing $5 \mathrm{G}$.

\subsubsection{Finding space for the spectrum}

Securing of locations for $5 \mathrm{G}$ is the greatest issue. "Currently, there are Enormous MIM gear units out there. In addition, each piece of equipment is installed the current location "as if the wheels had fallen off More towers and more wires will be required as the network expands. location will play a more notable role. 


\section{QALAAI ZANISTSCIENTIFIC JOURNAL \\ A Scientific Quarterly Refereed Journal Issued by Lebanese French University - Erbil, Kurdistan, Iraq}

Vol. (6), No (2), spring 2021

ISSN 2518-6566 (Online) - ISSN 2518-6558 (Print)

\subsubsection{Reasonable 5G devices}

On the buyer front, indeed in case $5 \mathrm{G}$ organize network comes in, reasonable $5 \mathrm{G}$ phones are created into the advertising. Prior to IMC, Qualcomm reported that they have accomplices working on reasonable $5 G$ gadgets but it's however to be seen when they will make their way to Iraq.

Table 1. Comparison of Mobile technologies

\begin{tabular}{|c|c|c|c|}
\hline Technology & 3G & 4G & 5G \\
\hline Requirements & $\begin{array}{l}\text { ITU"s IMT2000 required } \\
144 \text { kbps mobile, } 384 \\
\text { kbps pedestrian, } 2 \text { Mbps } \\
\text { indoor }\end{array}$ & $\begin{array}{l}\text { ITU"s IMT Advanced } \\
\text { requirements include } \\
\text { ability to operate in up to } \\
40 \mathrm{MHz} \text { radio channels } \\
\text { and with very high } \\
\text { spectral Efficiency }\end{array}$ & $\begin{array}{l}\text { at least } 1 \mathrm{~GB} / \mathrm{s} \text { or more } \\
\text { data rates to support } \\
\text { ultra-high definition } \\
\text { video and virtual } \\
\text { reality, applications, } \\
10 \mathrm{~GB} / \mathrm{s} \text { data rates to } \\
\text { support mobile cloud } \\
\text { service }\end{array}$ \\
\hline Data Bandwidth & $2 \mathrm{Mbps}$ & $2 \mathrm{Mbps}$ to $1 \mathrm{Gbps}$ & $\begin{array}{l}\text { 1Gbps \& Higher (as } \\
\text { demand) }\end{array}$ \\
\hline Core network & Packet network & All IP Network & $\begin{array}{l}\text { Flatter IP } \\
5 G \quad \text { Network \& } \\
\text { Interfacing(5G-NI) }\end{array}$ \\
\hline Service & $\begin{array}{l}\text { Integrated high quality } \\
\text { audio, video and data }\end{array}$ & $\begin{array}{l}\text { Dynamic information } \\
\text { access, wear-able devices, } \\
\text { HD streaming; global } \\
\text { roaming; }\end{array}$ & $\begin{array}{l}\text { Dynamic information } \\
\text { access, wear-able } \\
\text { devices, HD streaming; } \\
\text { any demand of users; } \\
\text { upcoming global } \\
\text { technologies; } \\
\text { roaming smoothly; }\end{array}$ \\
\hline Standards & WCDMA, CDMA 2000. & $\begin{array}{l}\text { All access convergence } \\
\text { including: OFMDA,MC- } \\
\text { CDMA Network-LMPS }\end{array}$ & CDMA \& BDMA \\
\hline
\end{tabular}

\section{Conclusion and Recommendations}

The world is increasingly requiring high connectivity for the many technological devices humankind has invented so far. The future also has expectations of remote surgical procedures done by robots, self-driven vehicles, smart homes and cities. All these devices and appliances need always-on and always-available, low latent and speed internet connections that the current 4G/LTE networks may not be able to 
sustain. The 5th Generation wireless network has therefore started making an entrance in the world - it promises to fulfill users' demands and at the same time maintain a balance between high data rates, connectivity density and low latency (Bergren, 2017). These are the $5 \mathrm{G}$ golden triangle requirements. However, it also has other requirements such as more capacity, reduced network energy usage and wider coverage to meet the sustainability and efficiency requirements.

However, though the network promises many good things, is faced with a myriad of challenges. They include privacy and security issues due to massive connections, regulation issues such as spectrum management, investment costs, the high expenses for building and buying a network, illiteracy levels, mmWave and D2D communication challenges and technology maturity (Taheribakhsh et al., 2020). Organizations and researchers propose some solutions for $5 \mathrm{G}$ successful implementation. They include having new multiple access such as Pattern Division Multiple Access (PDMA) and Sparse Code Multiple Access (SCMA) to increase the capacity, connection density, spectrum efficiency and data rates (Liu \& Jiang, 2016). Operators can also use new waveforms to maximize the use of spectrum, use massive MIMO technology to increase data rate, capacity and spectrum efficiency and new channel coding like polar code (Liu \& Jiang, 2016). End-to-end network slicing would help increase the flexibility of the $5 \mathrm{G}$ system to support all types of services. In the end, $5 \mathrm{G}$ wireless networks will bring some great necessities that will transform the world and hopefully meet the many user demands in this digital era. Perhaps, this great wireless technology might grant the many promises it has given to tech users.

\section{References:}

Agyapong, P. K., Iwamura, M., Staehle, D., Kiess, W., \& Benjebbour, A. (2014). Design considerations for a $5 \mathrm{G}$ network architecture. IEEE Communications Magazine, 52(11), 65-75. https://doi.org/10.1109/MCOM.2014.6957145

Ahmad, A. (2019, Feb 21). What Are the Technology Requirements for 5G? The Fast Mode. Retrieved from https://www.thefastmode.com/expert-opinion/14287-what-arethe-technology-requirements-for-5g 


\section{QALAAI ZANISTSCIENTIFIC JOURNAL \\ A Scientific Quarterly Refereed Journal Issued by Lebanese French University - Erbil, Kurdistan, Iraq \\ Vol. (6), No (2), spring 2021 \\ ISSN 2518-6566 (Online) - ISSN 2518-6558 (Print)}

Ahmad, I., Kumar, T., Liyanage, M., Okwuibe, J., Ylianttila, M., \& Gurtov, A. (2018). Overview of $5 \mathrm{G}$ security challenges and solutions. IEEE Communications Standards

Magazine, 2(1), 36-43. https://doi.org/10.1109/MCOMSTD.2018.1700063

Andrews, J. G., Buzzi, S., Choi, W., Hanly, S. V., Lozano, A., Soong, A. C., \& Zhang, J. C. (2014). What will $5 \mathrm{G}$ be?. IEEE Journal on selected areas in communications, 32(6), 10651082. https://doi.org/10.1109/JSAC.2014.2328098

Ayaz, M., Ammad-Uddin, M., Sharif, Z., Mansour, A., \& Aggoune, E. H. M. (2019). Internetof-Things (loT)-based smart agriculture: Toward making the fields talk. IEEE Access, 7, 129551-129583. https://doi.org/10.1109/ACCESS.2019.2932609

Bernardos, C. J., De Domenico, A., Ortin, J., Rost, P., \& Wübben, D. (2013, July). Challenges of designing jointly the backhaul and radio access network in a cloud-based mobile network. In 2013 Future Network \& Mobile Summit (pp. 1-10). IEEE.

Bergren, S. (2017). Design Considerations for a 5G Network Architecture. arXiv preprint arXiv:1705.02902. https://arxiv.org/abs/1705.02902v1

Chen, S., Liang, Y. C., Sun, S., Kang, S., Cheng, W., \& Peng, M. (2020). Vision, requirements, and technology trend of $6 \mathrm{G}$ : How to tackle the challenges of system coverage, capacity, user data-rate and movement speed. IEEE Wireless Communications, 27(2), 218-228. https://doi.org/10.1109/MWC.001.1900333

Dahlman, E., Mildh, G., Parkvall, S., Peisa, J., Sachs, J., Selén, Y., \& Sköld, J. (2014). 5 G wireless access: requirements and realization. IEEE Communications Magazine, 52(12), 42-47. https://doi.org/10.1109/MCOM.2014.6979985 


\section{QALAAI ZANISTSCIENTIFIC JOURNAL}

A Scientific Quarterly Refereed Journal Issued by Lebanese French University - Erbil, Kurdistan, Iraq

Vol. (6), No (2), spring 2021

ISSN 2518-6566 (Online) - ISSN 2518-6558 (Print)

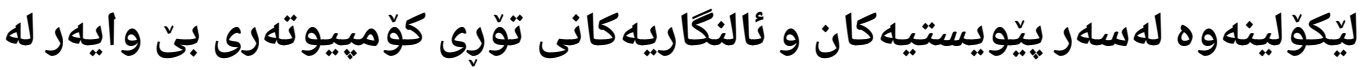 نهوهى يِينجههم}

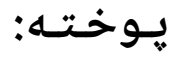

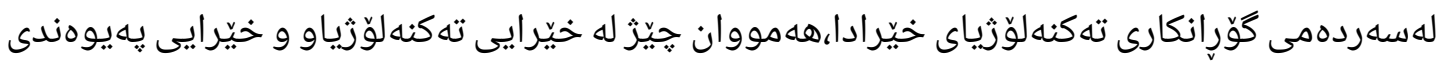
هيّلّى ئينتهرنيتى خيّرا دهبينين، بوّيه زوّر ئاساييه كه دهبينين كوّميانيا كهورهكان كاردهكهن به دريزّايى كات بوّ خيّرا كردنى سيستهمى ئينتهرنيّيتى خيّرا تايبهت بهخوّيان.ئاميّره ئه ليكتروّنيهكان كه مروّق

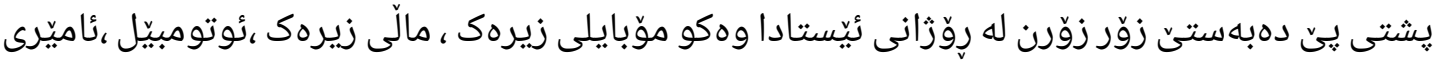
كوّمييوتهر و كاتزميّرى زيره ، ههموو ئهو ئاميّره يِيشكهوتووانه كه يِيويستيان به دئينتهرنيّتى

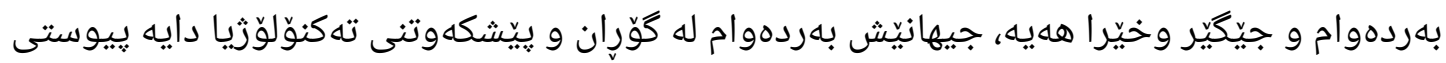

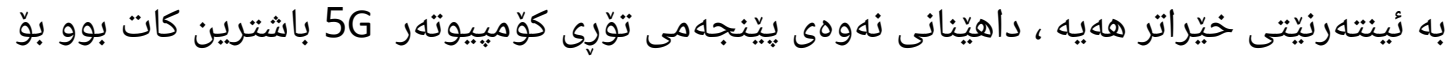

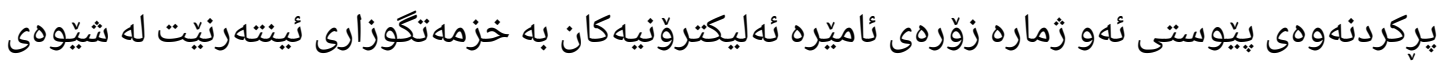

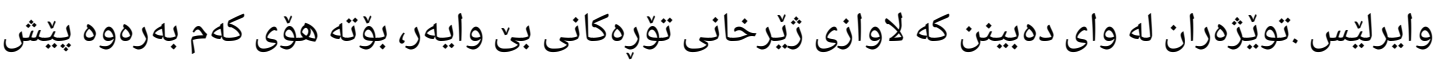

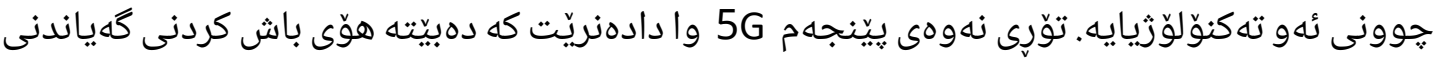
داتا و بهرزكردنهوهى كوّاليتى خزمهتكوزارى و كهم كردنهوهى كاتى گهيشتن و بهرز كردنهومى توانايى هيّلى ئينتهرنيّت .لهم تويّزينهوهدا تيشك دهخهينه سهر يِيّويستيه كانى ئهم ته كنولّوزيايه لهم سهردهمهـ و داواكاريه تهكنيكيه كانى توّريّ نهوهى يينجهم ،وهههروهها باسى ئهو ئالنكاريانه دهكهين كه ديته يِيش ههيكهلى كاركردنى نهوهى يِينجهم ،كه ريّكا دايه بوّ ئهوهى بييّته خيّراترين هيّلى بهيوهندى ئينتهرنيّت. 


\section{QALAAI ZANISTSCIENTIFIC JOURNAL}

A Scientific Quarterly Refereed Journal Issued by Lebanese French University - Erbil, Kurdistan, Iraq

Vol. (6), No (2), spring 2021

ISSN 2518-6566 (Online) - ISSN 2518-6558 (Print)

دراسة عن الضرورات والتحديات الحاضرة للشبكات اللاسلكية من الجيل الخامس

الملخص:

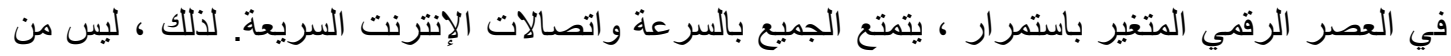

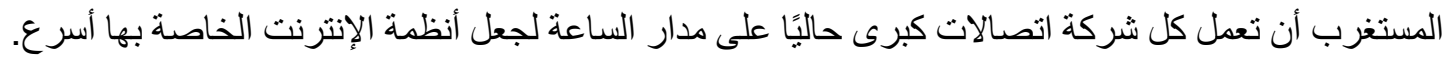

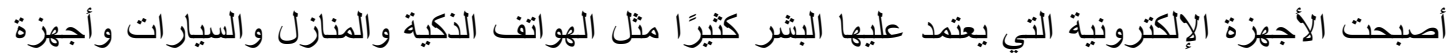

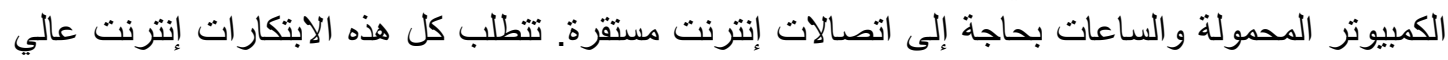

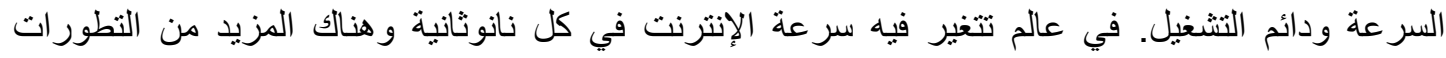

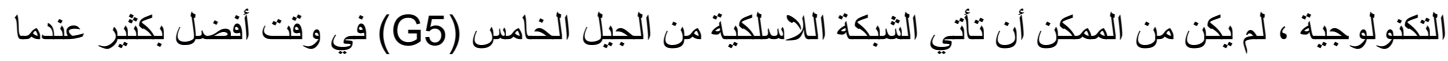

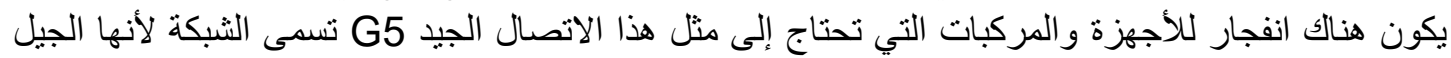

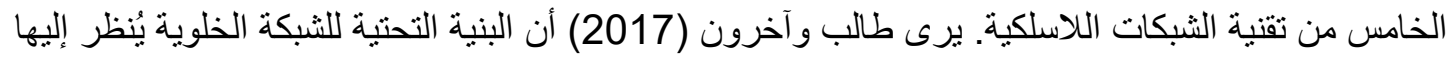

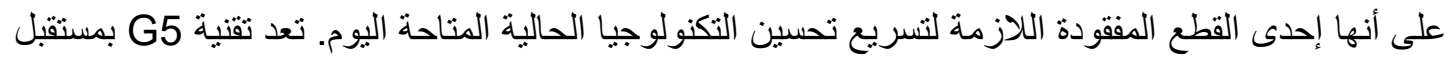

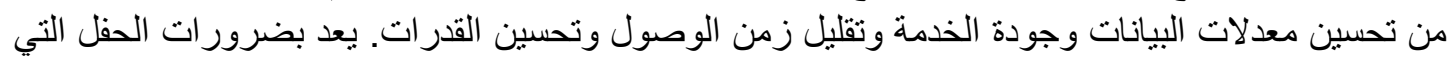

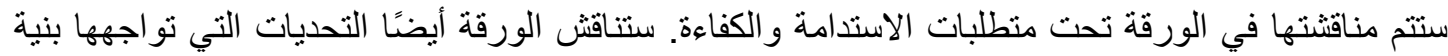
شبكة الهاتف المحمول G5 في رحلتها لتحقيق أسرع اتصال بالإنترنت على الإنى الإنلاق. 